\title{
6102 Sayılı Türk Ticaret Kanunu’na Göre Sermaye Şirketlerinde Tür Değişikliği ve Bir Uygulama**
}

\author{
Type Change and a Practice in Capital Companies According to Turkish Commercial Law No. 6102 \\ Süleyman Varol ${ }^{1 *(D)} \quad$ Adnan Dönmez ${ }^{2}$ (D)
}

${ }^{1}$ Program of Property Management, Alanya Aladddin Keykubat University, Alanya, Turkey

${ }^{2}$ Department of Business Administration, Akdeniz University, Antalya, Turkey

\begin{abstract}
$\begin{array}{lll}\text { Received: } 19.11 .2019 & \text { Accepted: } 08.08 .2020 & \text { This article was checked by } \text { intihal.net }\end{array}$
ISSN: $2149-8598$

$\ddot{O}_{z}$

Ekonomik hayatın önemli unsurlarından biri ticaret şirketleridir. Ticaret şirketlerinin birleşme, bölünme ve tür değiştirmeleri şirketlerin gelişmişlik düzeyi ve teknolojik gelişmelere bağlı olarak artan bir şekilde gündeme gelmektedir. Değişimlere katkı sağlayacak unsurların başında ülkelerin hukuk sistemlerinde gerekli düzenlemelerin zamanında yapılması gelmektedir. Avrupa Birliği (AB) uyum sürecinde yasal düzenlemelerde değişiklikler yapılmış olup bunlardan bir tanesi de 6102 sayılı Türk Ticaret Kanunu (TTK)'dur. Yapılan değişikliklerle kanun güncellenmiş olup eksik olan noktalar tamamlanmış, daha kapsamlı bir hale gelmiştir. İncelediğimiz konu sermaye şirketlerinde tür değişikliği olup, bu konuda TTK'da kapsamlı değişiklikler yapılmıştır. Bu çalışmada TTK'nın 180 ve 190. maddeleri dikkate alınarak, TTK, 6762 sayılı Türk Ticaret Kanunu (ETTK), konu ile ilgili makaleler v.b. kaynaklardan yararlanılarak sermaye şirketlerinde tür değişikliği ile ilgili getirilen yenilikler araştırılmış ve bir uygulama ile anlatılmıştır. Uygulama örneği; getirilen yenilikler ve avantajları sayesinde, TTK ile birlikte şirketler arasında en çok tür değişikliğin yapıldığı, bir limited şirketin anonim şirkete dönüşmesidir. Bu araştırma sonucu, sermaye şirketlerinde tür değişikliği ile ilgili getirilen yenilikler süreci izlenerek uygulanan örnekle konu pekiştirilmiştir.
\end{abstract}

Anahtar Kelimeler: 6102 Sayılı Türk Ticaret Kanunu, Sermaye Şirketleri, Tür Değiştirme

\section{Abstract}

One of the important elements of economic life is trading companies. Mergers, divisions and changes of trade companies are increasingly being brought to the agenda depending on the level of development and technological developments of the companies. One of the factors that will contribute to the changes is the timely implementation of the necessary arrangements in the legal systems of the countries. Changes have been made in the legal arrangements in the harmonization process of the European Union (EU), one of which is the Turkish Commercial Code (TCC) No. 6102. With the amendments, the law was updated and the missing points were completed and became more comprehensive. The issue we are examining is the type change in the capital companies and extensive changes have been made in the Turkish Commercial Code. In this study, taking into account articles 180 and 190 of the TCC, the TCC, Turkish Commercial Code No. 6762 (ETTK), related articles and so on. Using the resources, the innovations brought about the change in the type of capital companies were investigated and explained with an application. Application example; is the transformation of a limited liability company into a joint-stock company, through which innovations and advantages are introduced, the most common type of change between companies and TTK. As a result of this research, the subject was reinforced by following the process of innovations brought about the type change in the capital companies.

Keywords: Turkish Commercial Code No. 6102, Capital Companies, Type Change

Varol, S. \& Dönmez, A. (2020). “6102 Sayılı Türk Ticaret Kanunu’na Göre Sermaye Şirketlerinde Tür Değişikliği ve Bir Uygulama”, Journal of Academic Value Studies, 6(3) 288-310 (http://dx.doi.org/10.29228/javs.39820).

\footnotetext{
* E-mail address: suleyman.varol@alanya.edu.tr (Corresponding author)

** Bu çalışma, Süleyman VAROL tarafından Akdeniz Üniversitesi Sosyal Bilimler Enstitüsü’nde Prof. Dr. Adnan DÖNMEZ danışmanlığında tamamlanan “6102 Saylı Yeni Türk Ticaret Kanunu'na Göre Sermaye Şirketlerinde Bölünme, Birleşme ve Tür Değişikliği İle İlgili Yenilikler ve Bir Uygulama” başlıklı yüksek lisans tezinden üretilmiştir.
} 


\section{Giriş}

Şirket, bir veya daha fazla gerçek ve tüzel kişinin ortak ekonomik amaçlarını gerçekleştirmek üzere, emek ve sermayelerini bu ortak amaca ulaşmak için bir sözleşme ile birleştirerek oluşturdukları ticari kurumlardır. Şirketler; TTK'nın 124. maddesine göre şahıs ve sermaye şirketleri olmak üzere 2 ana grupta toplanmaktadır. Şahıs şirketleri kollektif ve adi komandit şirket olarak ayrılmakta, sermaye şirketleri ise limited, anonim ve sermayesi paylara bölünmüş komandit şirketten oluşmaktadır. Bu gruplandırmaların dışında kalan diğer şirketler ise kooperatifler ve adi şirketlerdir.

Ticaret şirketlerinde zamanla yapısal değişiklik gerekli olabilmektedir. Şirketlerdeki bu yapısal değişiklikler ya mali durumu iyileştirmek amacıyla ya da rekabet edebilirlik koşullarının güçlendirilmesi amacıyla yapılmakta olup, birleşme veya şirketin türünü değiştirmesi şeklinde olabilmektedir.

TTK'da yapılan en önemli değişikliklerden bir tanesi ticaret şirketlerindeki yapısal değişimlerdir. TTK'da ticaret şirketlerinin birleşme, bölünme ve tür değiştirmeleri düzenlenerek bu alanda önemli değişikliğe gidilmiştir. Burada amaçlanan; ticaret şirketlerinin iflas ettirilerek tasfiyeye gidilmeden, ortakların alacak ve pay haklarını koruyarak, sürekliliği bozmadan ve kolayca yapısal değişimlerini gerçekleştirebilmeleridir.

İsviçre'de 2003 yılında çıkarılan "Birleşme, Bölünme, Tür Değiştirme ve Malvarlığı Devrine İlişkin Federal Kanun” dan faydalanılarak TTK'nın 134-193. maddeleri oluşturulmuş, bu maddelerde şirketlerin birleşme, bölünme ve tür değiştirme ile yapılarının ve şekillerinin değiştirilebilmelerinin önü açılmıştır. Adalet Komisyonu aşamasında ticari işletmelerin birleşme ve tür değiştirmesi ile ilgili olan TTK 194. maddesi hükmü kanun metnine eklenmiştir. Baştaki iki (TTK, md.134-135), sonundaki üç maddede (TTK, md.191-193) ortak hükümlere yer verilmekle birlikte, 136-158. maddelerinde birleşmeye, 159-179. maddelerinde bölünmeye ve 180-190. maddeleri arasında ise tür değiştirmeye ilişkin hükümlere yer verilmektedir. ETTK'dan TTK'ya değiştirilirken, AB üyeliğine aday bir ülke olarak Avrupa Ekonomik Topluluğu/Avrupa Topluluğu düzenlemeleri (yönerge, tüzük, tavsiye, açıklamalar) dikkate alınmış, ayrıca genel gerekçesinde belirtildiği üzere teknolojik gelişmeler, internet ve ticari koşullardaki değişiklikler göz önünde bulundurularak günümüz ihtiyaçları doğrultusunda hazırlanmıştır.

Bu çalışma kapsamında öncelikle TTK'da sermaye şirketlerinde tür değiştirmeye ilişkin düzenlemelere yerildikten sonra, ETTK ve TTK karşılaştırılarak farklılıklara yer verilecek, daha sonra ise bir limited şirketin anonim şirkete dönüşümüne ilişkin gerçek bir vaka adım adım incelenecektir.

\section{Sermaye Şirketlerinde 6102 Sayılı Türk Ticaret Kanunu'na Göre Tür Değiştirme}

Şirketlerin tür değiştirmesi şirketlerin hukuki yapılarının değiştirilmesidir. Tür değişsirme TTK'da toplam 11 madde olarak, 180 ila 190. maddelerde düzenlenmiştir. Kanunun 180. maddesi ile şirketin hukuki yapısının değiştirilebileceği ve tür değiştiren şirketin eskisinin devamı olduğu hükmü getirilmiştir (Yerci, 2011: 46).

\section{1. Tür Değiştirmenin Unsurları}

Tür değiştirmenin temel unsurları şunlardır:

- Şirketin tür değiş̧irmeye kadarki genel olarak hukuki ilişkilerinin veya varlık ve kaynaklarının intikaline gerek kalmamaktadır.

- Türünü değiştiren şirket, hukuki ve ticari kimliğini korumaktadır.

- Malvarlığı ve ortaksal hak ve yükümlülüklerin devamlılı̆̆ ilkesi tür değiştirmede geçerli olduğundan, ortakların hakları ve yükümlülüklerinde tür değiştirme sonucu bir değişiklik olmayacaktır. Fakat tür değişikliği sebebiyle ortaya farklı hukuki durumlar çlkarsa, ortaklar bunlara katlanmak zorundadır (Pulaşlı, 2012: 192).

\section{2. Geçerli Tür Değiştirmeler}

TTK 181. maddede geçerli tür değiştirmeler belirtilmiştir. Buna göre;

a) Şahıs şirketlerinin, bir başka türdeki şahıs şirketine, sermaye şirketine ve kooperatife, 
b) Sermaye şirketlerinin bir başka türdeki sermaye şirketlerine ve kooperatife, dönüşmesi mümkün bulunmaktadır.

Geçerli tür değiştirmeler TTK madde 181'e uygun olarak Tablo 1'de gösterilmiştir.

Tablo 1. Geçerli Tür Değiştirmeler

\begin{tabular}{|l|l|}
\hline TÜR DEĞISTİREN & YENİ TÜR \\
\hline$\bullet$ Anonim Şirket & $\bullet$ Limited Şirket \\
& $\bullet$ SPBK Şirket \\
& $\bullet$ Kooperatif \\
\hline$\bullet$ Limited Şirket & $\bullet$ Anonim Şirket \\
& $\bullet$ SPBK Şirket \\
& $\bullet$ Kooperatif \\
\hline$\bullet$ Kooperatifler & $\bullet$ Anonim Şirket \\
& $\bullet$ Limited Şirket \\
& $\bullet$ SPBK Şirket \\
& $\bullet$ Anonim Şirket \\
& $\bullet$ Limited Şirket \\
& $\bullet$ SPBK Şirket \\
& $\bullet$ Kooperatif \\
& $\bullet$ Komandit Şirket \\
\hline$\bullet$ Komandit Şirket & $\bullet$ Anonim Şirket \\
& $\bullet$ Limited Şirket \\
& $\bullet$ SPBK Şirket \\
& $\bullet$ Kooperatif \\
& $\bullet$ Kollektif Şirket \\
\hline$\bullet$ Ticari İşletme (Şahıs İşletmeleri) & $\bullet$ Anonim Şirket \\
& $\bullet$ Limited Şirket \\
& $\bullet$ SPBK Şirket \\
\hline
\end{tabular}

Kaynak; Hayreddin, E. 2012, 239: 2-3

TTK 194. maddede ticari işletmelerle ilgili birleşme ve tür değiştirme düzenlenmiştir. Tabloda gösterilmemekle birlikte bu madde hükmünce ticaret şirketi ticaret şirketine dönüştürülebilmektedir ve madde 194/3'te aşağıdaki şekilde belirtilmiştir.

"Madde-194: (3) Bir ticaret şirketinin bir ticari işletmeye dönüştürülebilmesi için, söz konusu ticaret şirketinin paylarının tümü, ticari işletmeyi işletecek kişi veya kişiler tarafından devralınmalı ve ticari işletme bu kişi veya kişiler adına ticaret siciline tescil ve ilan edilmelidir. Bu hâlde, ticari işletmeye dönüştürülen ticaret şirketi, bir kolektif veya komandit şirket ise mezkûr ticaret şirketinin borçlarından, ticari işletmeyi işletecek kişi ve kişiler ile ticaret şirketinin eski ortakları da 264'üncü maddedeki zamanaşımı süresince sıfatlarına göre müteselsilen sorumlu olurlar. Dönüştürmeye bu Kanun'un 264 ilâ 266. maddeleri de uygulanır."

\section{3. Tür Değiştirmede Kollektif ve Komandit Şirketlere Özgü Düzenleme}

TTK madde 182 'de şahıs şirketlerinin kendi aralarında tür değiştirmesine özgü bir düzenleme yapılmıştır. Bu madde uyarınca yapılacak tür değiştirmelerinde, bir komandit şirketin bir kollektif şirkete veya bir kollektif şirketin bir komandit şirkete dönüşmesinde 180 ila 190 nncı madde hükümlerinin uygulanmayacağı belirtilmiştir.

Kollektif şirketin komandit şirkete dönüşebilmesi için kollektif şirket ortaklarından birinin komanditer ortağa dönüşmesi gerekmektedir. Bu gereklilikteki amaç komandit şirkette bulunması gereken komandite ve komanditer ortak türünün yerine getirilmesidir. Bu durumda şirket türüne ilişkin hükmün şirket sözleşmesinde öncelikli olarak değiştirilmesi gerekmektedir. Ortaklardan birinin komanditer ortağa dönüştürülmesi, ortakların şirket sözleşmesinde oybirliğiyle alacakları 
kararla mümkün olup, bu kararda yeni şirketin türü yani komandit şirket olduğu, komanditer ortağa ait sermayenin miktarı ve cinsi, ayrıca yönetim hakkı niteliği bulunmayan sadece komanditer ortak sıfatından kaynaklanan, komanditer ortaklara verilen görevlerin belirtilmesi gerekmektedir (Tepeli, 2012: 3).

TTK madde 182/2'de adi komandit şirketin kollektif şirkete dönüşebilmesi için bir düzenleme yapılmıştır ve bu düzenlemeye göre tür değişikliğinin gerçekleşebilmesi için adi komandit şirketteki tüm komanditer ortakların şirketten çıkması ya da tüm komanditer ortakların komandite ortak olması gerekmektedir.

Kanuna göre adi komandit şirkette diğer ortakların onay vermesi şartıyla, komanditer ortakların, şirketteki paylarını başkalarına devretmelerinde sakınca yoktur. Ancak Türk Borçlar Kanunu madde 632'ye göre devir işleminin gerçekleşebilmesi ve devralan kişinin ortaklık sıfatına haiz olabilmesi için diğer ortakların pay devrine ilişkin onay vermeleri gereklidir (TTK, md.315). Komanditer ortağın payını şirketteki komandite ortakları dışında bir kişiye devrettiği ve diğer ortakların payın devrini onayladıkları kabul edilse dahi tür değiştirme açısından bu işlemin bir anlamı yoktur. Çünkü devralan kişinin sıfatı komanditer ortak olacak, şirkette komanditer sıfatındaki ortaklık türünün varlığı devam edecektir. Ancak pay üçüncü bir kişiye değil de komandite ortaklardan birine devredilirse komanditer sıfatında ortak kalmayacak ve tür değiştirme için zemin hazırlanmış olacaktır.

Diğer taraftan, TTK madde 328'e göre, komandit şirketlerde bir ortağın şirketten çıkarılabilmesi için kollektif şirkete ait hükümler uygulanacak olmakla beraber iki şirket türü içinde benzer olan ve bir ortağın şirketten çıkarılması için gerekli olan haklı sebepler şunlardır:

- İflas etmek,

- Şirketin yönetim kanalıyla veya hesaplarını kullanarak şirkete ihanet etmek,

- Asli görev ve borçlarını yerine getirmemek, şirketin ticaret unvanını veya mallarını kişisel çıkarları için kötüye kullanmak,

- Üstlendiği şirket işlerini yerine getirmek için gerekli olan yetenek ve ehliyeti sürekli bir hastalık veya diğer sebeplerden dolayı kaybetmektir.

Yukarıda saydığımız haklı sebeplerin bulunması halinde diğer ortaklar ilgili ortağın şirketten çıkarılmasına karar verebilirler ve bu durumda şirket geri kalan ortaklarla devam edebilir. Saydığımız haklı sebeplerin yanı sıra süresiz olarak kurulan şirketlerde eğer ortaklardan biri fesih ihbarında bulunursa, diğer ortaklar şirketin feshini kabul etmeyerek, fesih ihbarında bulunan ortağın şirketten çıkarılmasına karar verebilirler ve şirket geri kalan ortaklarla devam edebilir (TTK, md. $245,254,255,256)$.

Sonuç olarak komandit şirkette komanditer ortağın şirketten çıkarılabilmesi noktasında sadece tür değiştirme gerekçesi yeterli bir gerekçe değildir ve kesinlikle belirtilen haklı sebeplerin varlığı gerekmektedir. Bununla beraber bir komandit şirketin komanditer ortakları belirtilen haklı sebeplerden biri nedeniyle şirketten çıkarılır ve başka komanditer ortak kalmazsa, komandit şirket kollektif şirkete dönüşebilecektir.

Gerek kanunda yer alan haklı sebeplerle komanditer ortağın diğer ortaklarca ortaklıktan çıkarılması gerekse komanditer ortağın payını komandite ortaklardan birine devretmesiyle şirketten ayrılması durumlarında şirket sözleşmesinin değiştirilmesi söz konusu olacaktır. Ayrıca tür değiştirerek kollektif şirket olmak isteyen komandit şirketin şirket türüne ilişkin sözleşme hükümlerini şirket sözleşmesinde değiştirmesi gerekmektedir. Yine de komandit şirketin şirket sözleşmesinde şirket türüne ilişkin değişiklik yapılmamış olsa dahi sadece komandite ortaklardan oluşan bir komandit şirket kollektif şirket sayılabilecektir. Çünkü şirketin komandit şirket olduğu belirgin bir şekilde tespit edilemiyorsa şirketin kollektif şirket sayılacağı TTK madde 306 ile hüküm altına alınmıştır. TTK madde 306'ya göre ortaklarca verilen şirketin adı ve niteliği şirket türünün belirlenebilmesi için yeterli kıstaslar değildir ve sadece komandite ortaklardan oluşan bir komandit şirket kollektif şirket sayılabilecektir (Tepeli, 2012: 3).

\section{4. Tür Değiş̧tirmede Şirket Payının ve Haklarının Korunması}

TTK'nın 183/1 hükmü gereğince, ortakların şirketteki pay ve haklarının korunması tür değiştirmede esastır. Bu esas uyarinca, 
- Tür değiştirme gerekçesiyle hiçbir ortağın şirketten çıkarılmasına karar verilemez,

- Tür değiştirme gerekçesiyle ortakların ortaklık haklarının zedelenmesi, azaltılması veya sınırlandırılması söz konusu olamaz.

Aynı fikra uyarınca, tür değiştirmede, oy hakkına sahip olmayan paylar için sahiplerince eşit değerde paylar ya da oy hakkına sahip payların verilmesi gerekir. Buna göre tür değiştirme sonucu şirkette oy hakkına sahip olmayan paylara karşlık aynı değerde oy hakkı olmayan paylar verilir fakat şirkette oy hakkı olmayan paylar çıkarılamıyorsa, eşdeğer oy hakkına sahip paylar ile durum eşitlenebilir.

TTK 183/3’te, tür değiştirmede, imtiyazlı paylar için eşit değerde payların verileceği ya da denk bir tazminat ödeneceği hükme bağlanmıştır. TTK 183/3'te de tür değiştirmede, intifa senetleri karşıllğıında eşit değerde hakların verileceği ya da tür değiştirme planının hazırlandığı tarihteki gerçek değeri üzerinden ödeme yapılacağı hüküm altına alınmıştır (Yerci, 2011: 54).

\section{5. Tür Değiştirme Süreci}

Tür değiştirme süreci, aşağıda tablodaki işlemlerin sırasıyla yerine getirilmesi ile gerçekleşmektedir TTK'nın 184 ila 189. maddeleri arasında kanunlaştırılan tür değiştirme süreci, Tablo 2'de özetlenmektedir.

Tablo 2. Tür Değiştirme Süreci

\begin{tabular}{|r|l|}
\hline 1 & Tür değişikliği için kuruluş sözleşmesinin hazırlanması ve gerekli ise ara bilanço çıkarılması, \\
\hline 2 & Tür değiştirme planının hazırlanması, \\
\hline 3 & Tür değiştirme raporunun hazırlanması, \\
\hline 4 & Tür değiştirme ile ilgili belgelerin ortakların incelemesine sunulması, \\
\hline 5 & Tür değiştirme planının genel kurulun onayına sunulması, \\
\hline 6 & Tür değişikliğinin ticaret siciline tescil edilmesi, \\
\hline 7 & Tür değişikliğinin ilanı. \\
\hline
\end{tabular}

\section{5. 1. Kuruluş ve Ara Bilanço}

Tür değiştirmede yeni türe ait kuruluş hükümlerinin uygulanması gerekmektedir ve bu durum TTK madde 184 ile hüküm altına alınmıştır. Ara bilanço çıkarılması veya çıkarılmaması konusunda ise birleşmeye ait hükümlerin yer aldığı TTK madde 144'e göre düzenleme yapılmıştır.

Tür değiştirmede son yıla ait bilanço esas alınarak yapılır. Ancak TTK madde 144 'te sözü edilen durumların varlığı halinde, tür değiştirecek olan şirket ara bilanço çıkarmak zorundadır. Bu durumlar; birleşme sözleşmesinin yapıldığı tarih ile yıllık bilanço tarihi arasındaki sürenin altı ayı geçmiş olması ve süreye bağlı olmaksızın birleşen şirketlerin varlıklarında önemli değişmelerdir. Bilanço tarihinin üzerinden altı aylık bir sürenin geçmesi olumlu veya olumsuz olarak bilançonun değer ve sonuçlarında değişikliğe sebep olmakla beraber, tam olarak bilanço değerlerinin saptanabilmesi ve birleşmenin hesaben yapılandırılabilmesi için yeni bir bilançoya yani ara bilançoya ihtiyaç vardır. Kanunda ara bilanço çıkarılırken fiziki envanter çıkarılmasına ihtiyaç olmadığı belirtilmiş, yıllık bilanço çıkarılırken uyulması gereken ilke ve esaslara göre düzenlenmesi istenilen ara bilançonun kolayca hazırlanması esas alınmışır (Öztürk, 2012: 4).

\section{5. 2. Tür Değiştirme Planı}

TTK'nın 185/1 hükmü uyarınca, bir şirket, tür değiştirecekse yönetim organının yazılı olarak bir tür değiştirme planı düzenlenmesi gerekir. Söz konusu planın aynı fikra uyarınca genel kurulun onayına tabi tutulması gerekmektedir (Yerci, 2011: 50). Tür değiştirme planın içeriği aşağıdaki gibidir:

- Şirketin tür değişikliğinden önceki ve sonraki ticaret unvanı, 
- Şirketin merkezi,

- Şirketin yeni türüne ait ibare,

- Şirketin yeni türüne göre düzenlenmişşirket sözleşmesi,

- Şirketin ortaklarının tür değişikliğinden sonraki paylarının sayı, cins ve tutarları veya paylarına ilişkin açıklamalar.

\section{5. 3. Tür Değiş̧tirme Raporu}

TTK’ya göre tür değişikliği yapılabilmesi için yönetim organı tarafından tür değiştirme planının yanında 186. maddeye göre "Tür Değiştirme Raporu"nun hazırlanması gerekmektedir. Rapor yönetim organı tarafından yazılı olarak hazırlanacak ve bu raporda maddede belirtilen hususlara yer verilecektir (Gülçiçek, 2012:79).

- Tür değiştirmedeki hedeflenen amaç ve sonuçlar,

- Yeni şirket türüne uygun kuruluş hükümlerinin yerine getirildiği,

- Yeni şirket türüne uygun olarak hazırlanmışşirket sözleşmesi,

- Tür değişikliğinden sonra ortakların paylarındaki değişim oranı ve yeni türden doğan yükümlülükleri,

- Tür değişikliği sebebiyle varsa ortaklara ait ek ödemeler, diğer kişisel edim yükümlülükleri ve sorumluluklar (Yerci, 2011: 51).

Ayrıca 186. maddeye göre küçük ve orta ölçekli şirketlerde ortakların oy birliği ile alacakları karar ile tür değiştirme raporunu düzenlenmesinden vazgeçilebilir.

\section{5. 4. İnceleme Hakkı}

TTK'nın 189/1 hükmü uyarınca, tür değiştirmenin şirketin genel kurulunca onaylanması gerekmektedir. Aynı kanunun "inceleme hakkı" başlığını taşıyan madde 188/1 hükmüne göre genel kurulda ilgili karar alınmasından 30 gün önce tür değiştirme planını ve raporunu, şirketin son üç yıla ait finansal tabloları ile birlikte varsa ara bilançosunu ortakların incelemesine sunması gerekmektedir.

Aynı hüküm uyarınca, tür değiştiren şirketin merkezinde, halka açık anonim şirketlerde ise merkezinin yanı sıra Sermaye Piyasası Kurulu tarafından belirlenen yerlerde belgeler incelenmek üzere ortaklara sunulur. Aynı hükmün 2 . fikrasınca ise ortaklar isterse yukarıda bahsedilen belgelerin kopyalarını bedelsiz olarak alabileceklerdir.

\section{5. 5. Tür Değiştirme Kararı ve Tescil}

TTK'nın 189. maddesi uyarınca şirketin yönetim organı tarafından tür değiştirme planının ve yeni türe ilişkin şirket sözleşmesinin, şirketi genel kuruluna sunulması gerektiği ve tür değiştirme kararının belirtilen nisaplarla karara bağlanması gerektiği hüküm altına alınmıştır. Tür değiştirme için gereken karar nisapları aşağıda Tablo 3 'te gösterilmektedir:

Tablo 3. Tür Değiştirmede Karar Nisapları

\begin{tabular}{|l|l|l|}
\hline \multicolumn{2}{|c|}{ TÜR DEĞİŞTİRMEDE GENEL KURUL NİSAPLARI } \\
\hline $\begin{array}{l}\text { TÜR DEĞİŞTİREN } \\
\text { ŞIRKET }\end{array}$ & NİSAP & DAYANAK \\
\hline $\begin{array}{l}\text { • Anonim Şirket } \\
\text { • Sermayesi Paylara } \\
\text { Bölünmüş Komandit } \\
\text { Şirket }\end{array}$ & $\begin{array}{l}\text { Esas veya çıkarılış sermayenin üçte ikisini karşılaması şartıyla, genel } \\
\text { kurulda mevcut oyların üçte ikisiyle; limited şirkete dönüştürme } \\
\text { halinde ek ödeme veya kişisel edim yükümlülüğü doğacaksa tüm } \\
\text { ortakların onayılyla alınır. }\end{array}$ & TTK md. 189/1-a \\
\hline$\bullet$ Sermaye Şirketleri & $\begin{array}{l}\text { Bir sermaye şirketinin bir kooperatife dönüşmesi halinde tüm } \\
\text { ortakların onayıyla karar alınır. }\end{array}$ & TTK md. 189/1-b \\
\hline$\bullet$ Limited Şirketler & $\begin{array}{l}\text { Sermayenin en az dörtte üçüne sahip bulunmaları şartıyla, } \\
\text { ortakların dörtte üçünün onayıyla karar alınır. }\end{array}$ & TTK md. 189/1-c \\
\hline
\end{tabular}




\begin{tabular}{|l|l|l|}
\hline - Kooperatifler & $\begin{array}{l}\text { 1- Ortakların en az üçte ikisinin temsil edilmeleri şartı ile genel } \\
\text { kurulda mevcut oyların çoğunluğuyla, } \\
\text { 2- Ek ödeme, diğer kişisel edim yükümlülükleri veya kişisel } \\
\text { sorumluluk getiriliyorsa veya bu yükümlülükler veya sorumluluklar } \\
\text { genişletiliyorsa, kooperatifte kayıtlı ortaklarının üçte ikisinin } \\
\text { olumlu oyuyla karar alınır. }\end{array}$ & TTK md. 189/1-d \\
\hline $\begin{array}{l}\text { - Kollektif Şirketler } \\
\text { - Komandit (Adi) Şirketler }\end{array}$ & $\begin{array}{l}\text { Tür değiştirme planı bütün ortakların oybirliğiyle onanır. Ancak, } \\
\text { şirket sözleşmesinde ortakların tümünün üçte ikisinin olumlu } \\
\text { oyuyla bu kararın alınabileceği öngörülebilir. }\end{array}$ & TTK md. 189/1-e \\
\hline
\end{tabular}

Kaynak; Hayreddin, E. 2012, 239: 5

TTK'nın 189/2 hükmü uyarınca, şirket yönetim organı tarafından tür değişikliğinin ve yeni şirketin sözleşmesinin Türk Ticaret Sicili’ne tescil ettirilmesi gerekir. Aynı fikra hükmü gereğince, tescil tür değiştirmeye hukuksal olarak geçerlilik kazandıran bir işlemdir.

\section{Bir Uygulama Örneği}

\section{1. Örnek Şirket Hakkında Genel Bilgi}

Şirket unvanı V OTOMASYON ÜRÜNLERİ SAN.VE TİC.LTD. ŞTİ.'dir. Şirketin merkezi D adresindedir. Şirketin iştigal konusu sanayide kullanılan makinelere otomasyon yapmaktır. Şirketin sermayesi 1.000.000,00€ değerindedir. Bu sermaye, her biri 1,00 TL değerinde 510.000 paya sahip 1.Ortak ve 490.000 paya sahip 2.Ortak olmak üzere iki ortağ1 bulunmaktadır.

Şirkette avantajlarından yararlanmak amacıyla limited şirketten anonim şirkete tür değişikliği yapılacaktır.

\section{2. Şirketin Tür Değişikliğinde Yapılacak İşlemler}

Şirket tür değişikliği yapılırken TTK'nın 180 ila 190. maddelerin yararlanılmaktadır. Tür değişikliği ile ilgili yol haritası Tablo 4'te gösterilmektedir.

Tablo 4. Tür Değişikliği Yol Haritası

\begin{tabular}{|r|c|}
\hline 1 & Limited Şirket Müdür/Müdürler Kurulu (Yönetim Organı) Tarafından Tür Değiştirme Kararı Alınması \\
\hline 2 & Bilanço/Ara Bilançonun Çıkartılması \\
\hline 3 & Yeni Kurulacak Şirkete Ait Esas Sözleşmenin Düzenlenmesi \\
\hline 4 & Müdür/Müdürler Kurulu Tarafından Tür Değiştirme Planı Hazırlanması \\
\hline 5 & Müdür/Müdürler Kurulu Tarafından Tür Değiştirme Raporunun Hazırlanması \\
\hline 6 & Tür Değiştirme İşlemlerinin Ortakların İncelemesine Açılması \\
\hline 7 & $\begin{array}{c}\text { Tür Değiş̧irme Planının Genel Kurulun Onayına Sunulması (Genel Kurulun Toplanması ve Karar } \\
\text { Alması) (Karar Ortakların Dörtte Üçünün Kararıyla Alınır) }\end{array}$ \\
\hline 8 & Genel Kurul Kararının Ticaret Sicilinde Tescil ve İlanı \\
\hline
\end{tabular}

Kaynak; Hayreddin, E. 2012, 239: 3

\section{2. 1. Tür Değiştirme Kararı}

Yönetim organı tarafından alınan aşağıdaki karar ile tür değişikliğine adım atılmıştır.

V OTOMASYON ÜRÜNLERI SANAYİ VE TİCARET LIMİTED ŞİRKETİ

SİCİL NO : XXX 
KARAR NO : XXX/XX

KARAR TARİHI $\quad$ : XX/XX/XXXX

Şirket ortakları şirket merkezinde toplanarak aşağıdaki hususları karar altına almışlardır:

1)TTK'nın 180 ila 193. maddeleri ile Kurumlar Vergisi Kanunu'nun 19 ve 20. maddelerine göre tür değiştirmek suretiyle tüm aktif ve pasifleriyle bir bütün halinde anonim şirkete dönüştürülmesine,

2)Tür değiştirme işlemi ile ilgili olarak 31.03.2013 tarihi itibariyle şirketin ara bilanço çıartılmasına, öz varlık tespiti için Serbest Muhasebeci Mali Müşavirden rapor alınmasına,

3)Yeni kurulacak şirketin unvanının V OTOMASYON ÜRÜNLERİ SANAYİ VE TİCARET ANONİM ŞİRKETI olmasina,

4)Kurulacak anonim şirketin sermayesinin 5.000.000,00€ olmasına ve bu sermayenin limited şirketin esas sermayesinden, geçmiş yıl karlarından ve sermaye düzeltmesi olumlu farklarından karşılanmasına,

Tür değişikliği planının hazırlanarak ortakların incelenmesine sunulmasına, oy birliği ile karar verilmiştir.

ORTAK

1. ORTAK
ORTAK

2.ORTAK

\section{OTOMASYON ÜRÜNLERİ SANAYİ VE TICARET LIMITED ŞİRKETI}

SİCİL NO : XXX

KARAR NO : XXX/XX

\section{KARAR TARIHHI: XX/XX/XXXX}

Şirket ortakları şirket merkezinde toplanarak aşağıdaki hususları karar altına almışlardır:

1)TTK’nın 180 ila 193. maddeleri ile Kurumlar Vergisi Kanunu’nun 19 ve 20. maddelerine göre tür değiştirmek suretiyle tüm aktif ve pasifleriyle bir bütün halinde anonim şirkete dönüştürülmesine,

2)Tür değiştirme işlemi ile ilgili olarak 31.03.2013 tarihi itibariyle şirketin ara bilanço çıartılmasına, öz varlık tespiti için Serbest Muhasebeci Mali Müşavirden rapor alınmasına,

3)Yeni kurulacak şirketin unvanının V OTOMASYON ÜRÜNLERİ SANAYİ VE TİCARET ANONİM ŞİRKETİ olmasina,

4)Kurulacak anonim şirketin sermayesinin 5.000.000,00€ olmasına ve bu sermayenin limited şirketin esas sermayesinden, geçmiş yıl karlarından ve sermaye düzeltmesi olumlu farklarından karşılanmasına,

Tür değişikliği planının hazırlanarak ortakların incelenmesine sunulmasına, oy birliği ile karar verilmiştir.

ORTAK

1. ORTAK

(AD-SOYAD, TC, İMZA)
ORTAK

2.ORTAK

(AD-SOYAD, TC, IMZA)

\section{2. 2. Bilanço veya Ara Bilanço Çıkarma}

Şirketin sermayesinde olan değişiklik nedeniyle ara bilanço çıkarılması gerekmektedir. Ara bilanço aşağıdaki gibidir: 
Örnekle İlgili Bilanço I

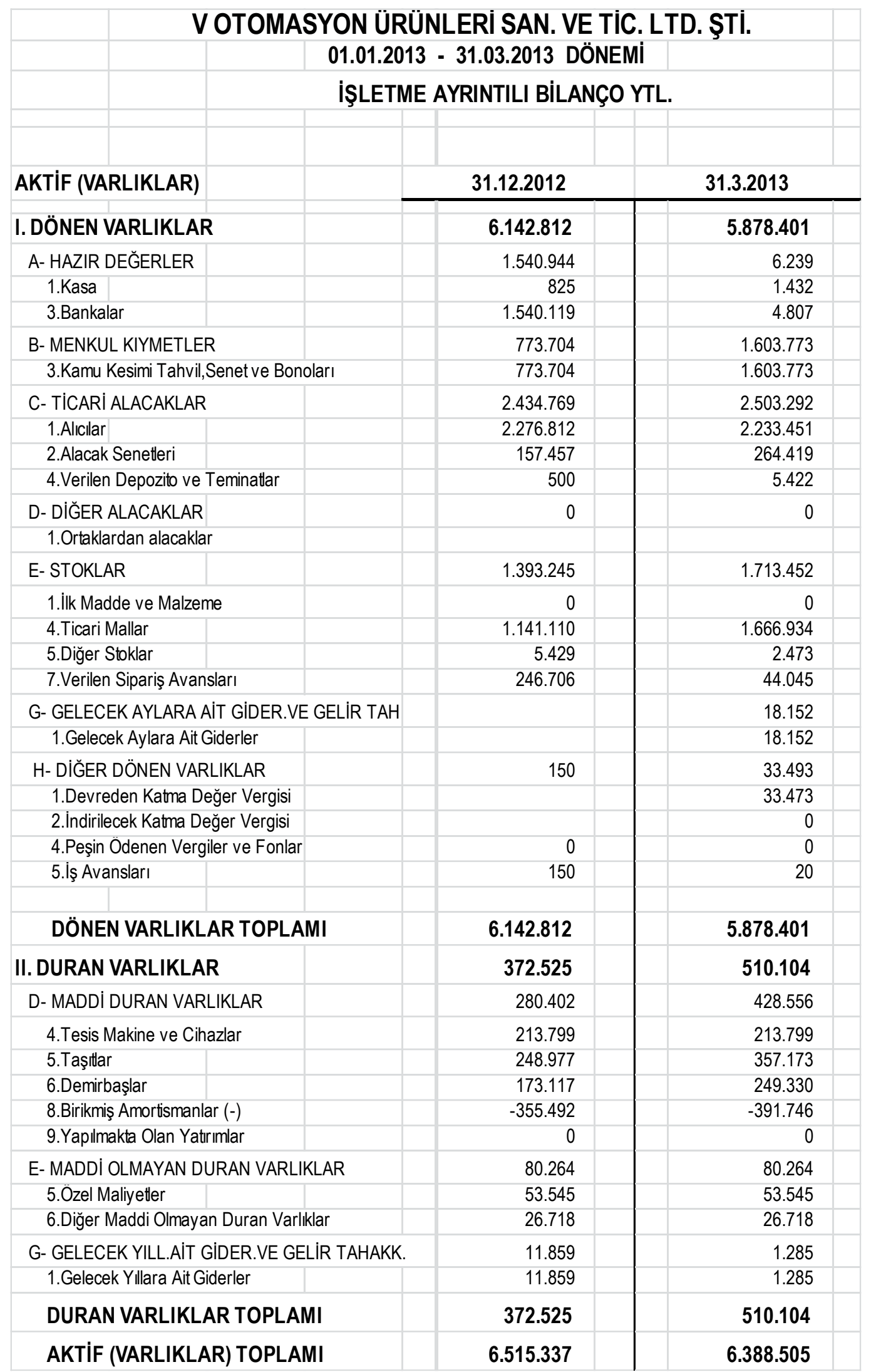


Örnekle İlgili Bilanço II

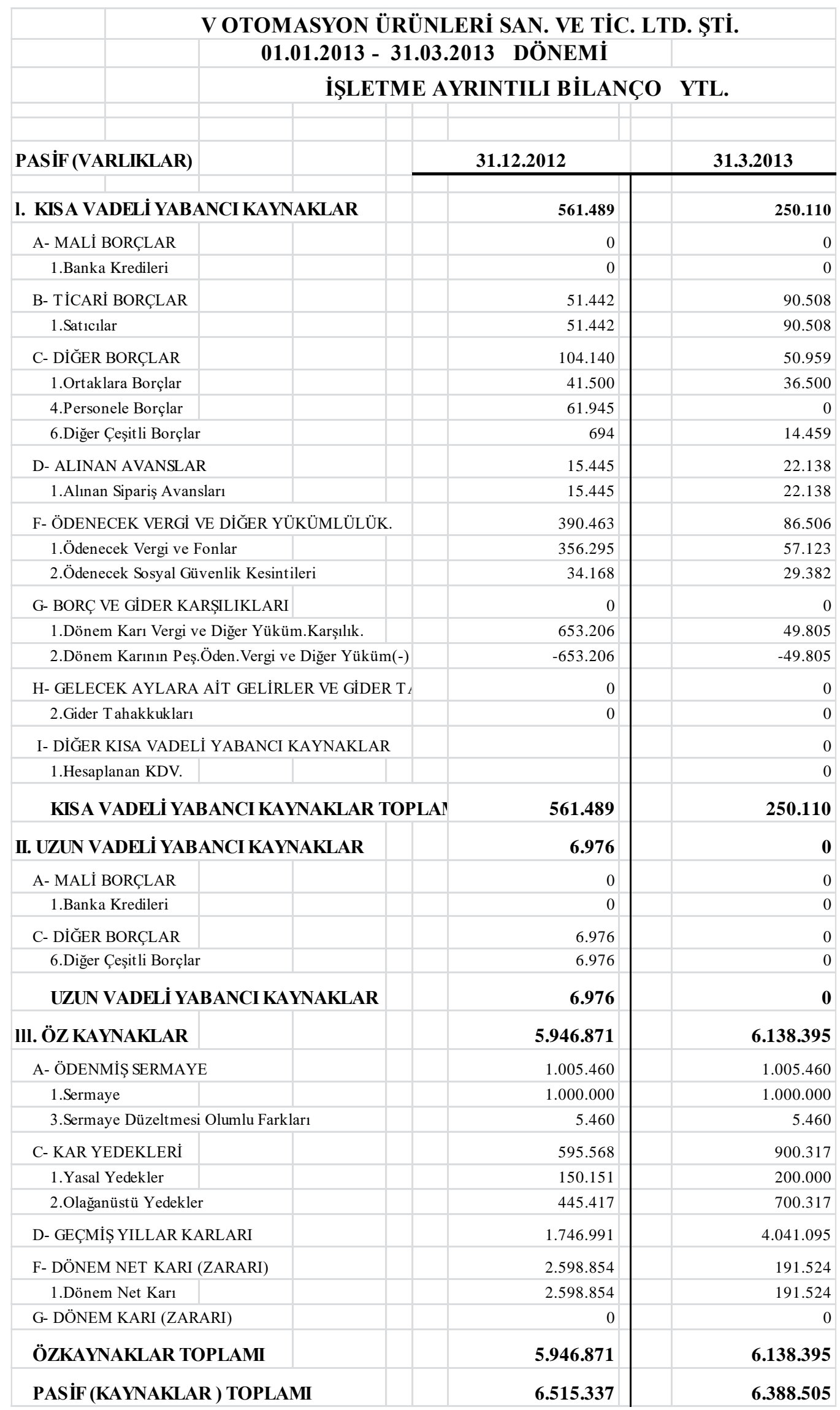




\section{2. 3. Anonim Şirketin Esas Sözleşmesi}

Şirket tür değişikliği için esas sözleşmeyi aşağıdaki gibi düzenlenmiştir.

V OTOMASYON ÜRÜNLERİ SANAYİ VE TİCARET ANONIM ŞİRKETİ ESAS SÖZLEŞMESİ

1) KURULUŞ

Madde 1- İstanbul Ticaret Sicili Müdürlüğü'nün 513429 sayısında kayıtlı V Otomasyon Ürünleri Sanayi ve Ticaret Limited Şirketi'nin TTK’nın 180 ila 193. maddelerine göre tür değiştirmesi suretiyle; aşağıda, adları, soyadları, yerleşim yerleri ve uyrukları yazılı kurucular arasında bir anonim şirket kurulmuştur.

$\begin{array}{llll}\text { Kurucunun Adı Soyadı } & \text { T.C. Kimlik No } & \text { İkametgâh Adresi } & \text { Uyruğu } \\ \text { 1- 1.ORTAK } & \text { XXXXXXXXXX } & \text { K ADRESİ } & \text { T.C. } \\ \text { 2- 2.ORTAK } & \text { XXXXXXXXXXX } & \text { L ADRESİ } & \text { T.C. }\end{array}$

\section{2) ŞİRKETIN UNVANI:}

Madde 2- Şirketin unvanı V Otomasyon Ürünleri Sanayi ve Ticaret Anonim Şirketi'dir.

\section{3) AMAÇ VE KONU}

Madde 3- Şirketin amaç ve konusu başlıca şunlardır:

1-Sanayide (otomotiv, tekstil, plastik, gıda, ambalaj, beyaz eşya, elektrikli, elektronik eşyalar gibi) kullanılan her çeşit makine, alet ve yedek parçalarını sağlamak ve imalatını yapmak.

2- Kara, deniz, hava nakil vasıtaları ile iş makinelerinin hidrolik, pnömatik, elektrik, elektronik donanımları ile bunlara ilişkin yedek parçaları sağlamak.

3- Elektronik ve iletişim bazlı her türlü makine ve ekipman, dijital video, disk ve diğer bantların ve bunların lazer haline getirilmiş türlerinin bilgisayar ve çeşitli kayıt yapan, okuyan ve gösterim cihazlarının otomasyonu ile gerek aletin kendisinin gerekse yedek parçasını sağlamak.

4- Turistik işyerleri, lunapark gibi eğlence merkezlerinin iş merkezleri ile konutların spor tesislerinin, hidrolik, pnömatik, elektrik, elektronik işlerinin otomasyonu ile bunlara ait makine ve yedek parçalarını sağlamak.

Şirket konusu ile ilgili aşă̆ıdaki işleri de yapabilir; sağlamak,

1- Konusu ile ilgili her türlü eğitim, seminer düzenlemek, tanıtım, kitap ve broşürlerin yayımını, dağıtılmasını

2- Konusu ile ilgili resmi ve özel kuruluşlar nezdinde taahhüt ve müteahhitlik işleri yapılması, ihalelere girilmesi,

3- Konusu ile ilgili mamul, yarı mamul, hammadde, enerji, işletme ve tamir malzemesinin, dayanıklı tüketim mallarının, maden, plastik ve sair malzemeden mamul emtianın, makine, techizat, gemi ve uçak dahil taşıt araçlarının alınması, satılması, ithal ve ihraç edilmesi, kiralanması, kiraya verilmesi,

4- Konusu ile ilgili üretim ve sınai tesisler kurulması ve konusu ile ilgili malların satımını yapabilmek için teşhir ve satış mağazaları açılması, devredilmesi, işletilmesi,

5- Konusu ile ilgili kurulmuş ve kurulacak olan şirketlere iştirak edilmesi,

6- Aracılık faaliyetlerinde bulunmamak koşulu ile özel hukuk ve kamu hukuku tüzel kişileri tarafından çıarılan hisse senetlerinin, tahvillerin, intifa senetlerinin sair menkul kıymetler ve sermaye piyasası araçlarının iktisap edilmesi ve üzerinde her türlü hukuki tasarrufta bulunulması,

7- Şirketin amaç ve konusu ile ilgili veya yardımcı veya onu kolaylaştırıcı gayrimenkullerin iktisabı veya inşası, stüdyolar inşası ve üzerinde her türlü hukuki tasarruflarda bulunulması, şirkette ortaklara, müdürlere veya şirket personeline 
tahsis edilmek üzere kiralanması, kiraya verilmesi, şirketin amaç ve konusunu gerçekleştirmesi için ipotek veya başka bir teminat karşıllğı veya teminatsız ödünç alınması, ipotek rehin ve ticari işletme rehni tesis edilmesi ve bunların feshedilebilmesi, üçüncü kişilere ivazlı veya ivazsız borç verilmesi, borçlarına kefil olunması,

8- Şirketin konusu ile ilgili faaliyetler için faydalı ihtira haklarının, ihtira beratlarının, patent, lisans ve imtiyazlarının, marka, model, resim ve diğer ticaret unvanlarının telif haklarının, "know-how"ın, "copyright"ların, hususi imal ve istihsal usullerinin ve benzeri diğer gayri maddi hakların iktisap edilmesi, üzerlerinde her türlü hukuki tasarrufta bulunulması,

Şirket amacını gerçekleştirmek için her türlü gayrimenkul alabilir, satabilir, kiralar, kiraya verir bunlar üzerinde ayni ve şahsi her türlü hakları tesis edebilir, ipotek alabilir, ipotek verebilir ve ipotekleri fek edebilir. Şirket gayrimenkulleri üzerinde irtifak, intifa, sükna, gayrimenkul mükellefiyeti, kat irtifakı, kat mülkiyeti tesis edebilir. Her türlü gayrimenkullerle ilgili olarak tapu daireleri nezdinde cins tashihi, ifraz, tevhit, taksim, parselasyon ile ilgili her nevi muamele ve tasarrufları gerçekleştirebilir.

\section{4) MERKEZI}

Madde 4- Şirketin merkezi B İli, C İlçesi'ndedir. Adresi; D’dir. Adres değişikliğinde yeni adres, ticaret siciline tescil ve Türkiye Ticaret Sicil Gazetesi’nde ilan ettirilir. Tescil ve ilan edilmiş adrese yapılan tebligat şirkete yapılmış sayılır. Tescil ve ilan edilmiş adresinden ayrılmış olmasına rağmen yeni adresine süresi içinde tescil ettirmemiş şirket için bu durum fesih sebebi sayllır.

\section{5) ŞİRKETİN SÜRESİ:}

Madde 5- Şirketin süresi, kuruluşundan itibaren süresizdir. Bu süre şirket sözleşmesini değiştirmek suretiyle uzatılıp kısaltılabilir.

\section{6) SERMAYE VE PAY SENETLERINIIN TÜRÜ}

Madde 6- Şirketin sermayesi 5.000.000,00€ değerindedir. Bu sermaye, her biri 1,00€ değerinde 5.000.000 paya ayrilmıştır.

Bundan 2.500.000 paya karşılık 2.500.000,00€’'si, 1.ORTAK,

Bundan 2.500.000 paya karşılık 2.500.000,00€’si, 2.ORTAK,

Tarafından tamamı taahhüt edilmiştir. Taahhüt edilen sermayenin 1.000.000,00£'lik kısmı TTK'nın 180 ila 193. maddelerine göre tür değiştiren V Otomasyon Ürünleri Sanayi ve Ticaret Limited Şirketi'nin ödenmişs sermayesinden karşılanmıştır. Geri kalan 3.994.540,50€ geçmiş yl karlarından, 5.459,50€ sermaye düzeltmesi olumlu farklarından karşılanmıştır. Tür değiştiren şirketin öz varlığının tespiti, dağıılmayan geçmiş yıl karlarının sermayeye ilavesinin tespiti ve sermaye düzeltmesi olumlu farklarının sermayeye eklenmesinin tespiti SMMM E... .... Tarafından düzenlenen XX.XX. XXXX tarihli XXX-X sayılı raporu ile tespit edilmiştir.

Hisse senetleri nama yazılıdır. Hisse senetleri 1€ (bir TL) itibari değerinin katları şeklinde küpürler halinde basılabilir.

Limited şirketin faaliyetinden doğan tüm borç ve alacakların taahhüt ve mükellefiyetlerinden ötürü sorumluluğu işbu anonim şirkette aynen devam edecektir.

Tür değişikliği yolu ile kurulan anonim şirket TTK'nın 180 ila 193. maddeleri uyarınca eski şirket V Otomasyon Ürünleri Sanayi ve Ticaret Limited Şirketi'nin devamıdır.

Bu itibarla limited şirketin bütün aktif ve pasifi mal varlığg bütün hak ve vecibeleri taahhütleri yeni anonim şirkete başkaca bir işleme ihtiyaç kalmaksızın devrolmuştur. Anonim şirket limited şirketin faaliyetlerine ara vermeksizin devam edecektir.

\section{7) YÖNETIM KURULU VE SÜRESİ:}

Madde7- Şirketin işleri ve idaresi genel kurul tarafından TTK'nın hükümleri çerçevesinde seçilecek en az 1 (bir) veya 1 (bir) ila 5 (beş) arasında değişen sayıda üyeden oluşan bir yönetim kurulu tarafından yürütülür. Yönetim kurulu üyeleri en çok 3 yıl için seçilebilirler. Görev süresi sona eren yönetim kurulu üyeleri yeniden seçilebilirler. 


\section{8) ŞİRKETIN TEMSILII VE YÖNETIM KURULU ÜYELERININN GÖREV DAĞILIMI:}

Madde 8- Şirketin yönetimi ve dışarıya karşı temsili yönetim kuruluna aittir. Şirket tarafından verilecek bütün belgelerin ve yapılacak sözleşmelerin geçerli olabilmesi için bunların şirket unvanı alına konmuş ve şirketi ilzama yetkili kişi veya kişilerin imzasını taşıması gereklidir. Yönetim kurulu şirketi temsil yetkisinin hepsini veya bir kısmını yönetim kurulu üyesi olan bir veya birkaç üyeye veya pay sahibi olmaları zorunlu olmayan müdürlere bırakabilir.

\section{9) GENEL KURUL:}

Madde 9- Genel kurullar, olağan ve olağanüstü toplanırlar. Olağan genel kurul, şirketin hesap devresi sonundan itibaren 3 ay içinde ve senede en az bir defa; olağanüstü genel kurullar ise, şirket işlerinin gerektirdiği hallerde ve zamanlarda toplanır.

Genel kurul toplantılarında, her pay sahibinin oy hakkı, sahip olduğu payların itibari değerleri toplamının, şirket sermayesinin itibari değerinin toplamına oranlanmasıyla hesaplanır. Pay sahibi genel kurul toplantılarına kendisi katılabileceği gibi pay sahibi olan veya olmayan bir temsilci de yollayabilir.

Şirket genel kurul toplantılarında, TTK'nın 409. maddesinde yazılı hususlar müzakere edilerek gerekli kararlar alınır. Genel kurul toplantıları ve bu toplantılardaki karar nisabı, Türk Ticaret Kanunu hükümlerine tabidir.

Genel kurul, şirketin merkez adresinde veya yönetim merkezinin bulunduğu şehrin elverişli bir yerinde toplanır.

10) İLAN:

Madde 10- Şirkete ait ilanlar, TTK’nın 35. maddesinin dördüncü fikrası hükmüne göre yapılır.

Genel kurulun toplantıya çağırılmasına ait ilanlar TTK’nın 414. maddesi hükmü gereğince ilan ve toplantı günleri hariç olmak üzere en az iki hafta önce yapılması zorunludur.

\section{1) HESAP DÖNEMİ:}

Madde 11- Şirket hesap yılı ocak ayının birinci gününden başlar ve aralık ayının sonuncu günü sona erer. Fakat birinci hesap yılı şirketin kesin olarak kurulduğu tarihten itibaren başlar ve o senenin aralık ayının sonuncu günü sona erer.

\section{2) KARIN TESPITTI VE DAĞITIMI:}

Madde 12- Şirketin net dönem karı yapılmış her çeşit masrafların çıkarılmasından sonra kalan miktardır. Net dönem kârından her yıl \%5 genel kanuni yedek akçe ayrılır; kalan miktarın \%5’i pay sahiplerine kâr payı olarak dağıtılır. Kâr payı, pay sahibinin esas sermaye payı için şirkete yaptı̆̆ı ödemelerle orantılı olarak hesaplanır.

Net dönem karının geri kalan kısmı, genel kurulun tespit edeceği şekil ve surette dağıtılır. Pay sahiplerine $\% 5$ oranında kâr payı ödendikten sonra kardan pay alacak kişilere dağıtılacak toplam tutarın \%10'u genel kanuni yedek akçeye eklenir.

13) YEDEK AKÇE:

Madde 13- Şirket tarafından ayrılan ihtiyat akçeleri hakkında TTK'nın 519 ila 523. maddeleri hükümleri uygulanır.

14) KANUNİ HÜKÜMLER:

Madde14- Bu esas sözleşmede bulunmayan hususlar hakkında Türk Ticaret Kanunu hükümleri uygulanır.

15) GEÇİCİ HÜKÜMLER:

KURULUŞ GIDDERLERİ

GEÇİCİ MADDE 1:

Şirketin kuruluşuna ilişkin, kurucular tarafından yapılan ve kuruluş için gerekli addolunan bilcümle harcamalar şirketin masraflarına intikal ettirilir.

İLK YÖNETIMM KURULU ÜYELERİ

GEÇİCİ MADDE 2: 
İlk yönetim kurulu üyesi olarak: Başkanlığa XXXXXXXXXXX T.C. kimlik numaralı K adresinde oturan 1.ORTAK, Başkan Yardımcılı̆̆ına XXXXXXXXXXX T.C. kimlik numaralı L adresinde oturan 2.ORTAK seçilmişlerdir. İlk yönetim kurulu üyeleri 3 (üç) yıl için seçilmişlerdir

TEMSIL

\section{GEÇİCI MADDE 3:}

Aşağıda adları, soyadları görevleri ve yetki dereceleri belirtilen kişilerin, şirketimizi aşağıdaki şekilde temsil ve ilzam etmelerine;

a- Yönetim Kurulu Başkanı 1.ORTAK şirket kaşesi veya unvanı altında atacağı münferit imzasıyla şirketi her konuda temsil ve ilzam etmesine,

b- Yönetim Kurulu Başkan Yardımcısı 2.ORTAK şirket kaşesi veya şirket unvanı altında atacakları müşterek imzaları ile şirketi her konuda temsil ve ilzam etmesine yetkilidirler.

\section{2. 4. Şirketin Tür Değiştirme Planı}

Tür değiştirmede önemli adımlardan olan tür değiştirme planı Ek-2'de sunulmuştur.

a) Şirketin tür değiştirmeden önceki unvanı:

\section{OTOMASYON ÜRÜNLERİ SANAYİ VE TİCARET LIMIITED ŞİRKETİ}

b) Şirketin tür değişikliğinden sonraki unvanı:

\section{OTOMASYON ÜRÜNLERİ SANAYİ VE TİCARET ANONIM ŞİRKETİ}

c) Şirketin merkezi:

D ADRESI

d) Şirketin yeni türü:

\section{ANONIM ŞİRKET}

e) Yeni şirketin esas sözleşmesi: Bir önceki konuda yer verilmektedir.

f) Ortakların tür değiştirmeden önce sahip oldukları paylara ilişkin bilgi:

\begin{tabular}{llll} 
ORTAĞIN ADI SOYADI & PAY ORANI & HISSE ADEDI & PAY TUTARI \\
\hline 1.ORTAK & $\% 51$ & 510.000 & $510.000,00 €$ \\
2.ORTAK & $\% 49$ & 490.000 & $490.000,00 €$
\end{tabular}

g) Ortakların tür değiştirdikten sonra sahip olacakları paylara ilişkin bilgi:

$\begin{array}{llll}\text { ORTAĞIN ADI SOYADI } & \text { PAY ORANI } & \text { HISSE ADEDİ } & \text { PAYTUTARI } \\ \text { 1.ORTAK } & \% 50 & 2.500 .000 & 2.500 .000,00 € \\ \text { 2.ORTAK } & \% 50 & 2.500 .000 & 2.500 .000,00 €\end{array}$

Yapılması öngörülen tür değişikliği sonucunda ortak sayısında ve ortakların şirketteki paylarında yukarıda gösterilen şekilde değişiklik meydana gelecek, sermaye geçmiş yıl karlarının ve sermaye düzeltmesi olumlu farklarının sermayeye eklenmesi ile 5.000.000,00£’ye çıkartllacaktır. Tür değişikliği limited şirketin 31.03.2013 tarihli ara bilançosuna göre hesaplanacak öz varlık tutarı esas alınarak gerçekleştirilecek olup, limited şirketin aktif ve pasifi bir bütün olarak yeni kurulacak anonim şirkete devredilecektir.

İşbu “tür değiştirme planı” 28.02.2013 tarihinde TTK'nın 185. maddesi uyarınca hazırlanmıştır. 
1.ORTAK

(AD-SOYAD, TC, IMZA)
2.ORTAK

(AD-SOYAD, TC, İMZA)

\section{2. 5. Şirketin Tür Değiştirme Raporu}

Şirket “Küçük ve Orta Büyüklükteki İşletmelerin Tanımı, Nitelikleri Sınıflandırılması Hakkındaki Yönetmelik” gereği küçük ve orta büyüklükte ölçekli işletme sınıfında yer almakta, istihdam ettiği kişi sayısı, net satış hasılatı ve mali bilanço toplamına ilişkin bilgileri Ek-3'te tür değiştirme raporunda sunulmuştur. Ayrıca istenirse, ortakların oy birliği ile alacakları karar ile tür değiştirme raporunu düzenlenmesinden vazgeçebilirler. Örnek olması açısından tür değiştirme raporu düzenlenmiştir.

\section{ŞİRKETİN TÜR DEĞİSTİRME RAPORU}

Rapor Sayısı: XXX/X

$\mathrm{XX} / \mathrm{XX} / \mathrm{XXXX}$

ÖZ VARLIĞIN, TESCİLE TABİ VARLIKLARIN DEĞER TESPİTINE, KOBİ STATÜSÜNÜNTESPİTINE, SERMAYENIN ÖDENDIGĞININ TESPITTINE, DAĞITILMAYAN GEÇMIŞ YIL KARLARININ SERMAYEYE ILAVESININ TESPITINE VE SERMAYE DÜZELTMESİ OLUMLU FARKLARININ SERMAYEYE İLAVESININ TESPITTINE İLIŞKIN RAPORU

1-İNCELEMEYİ YAPAN SERBEST MUHASEBECİ MALİ MÜŞAVİRİN:

$\begin{array}{ll}\text { ADI SOYADI } & : \text { XXXXXX XXXX } \\ \text { BAĞLI BULUNDUĞU ODA } & : \text { XXXXXX ODASI } \\ \text { RUHSAT NUMARASI } & : \text { XXXXXXX } \\ \text { ODA SİCİL NUMARASI } & : \text { XXXXX } \\ \text { BÜRO SİCİL NUMARASI } & : \text { XXXXX } \\ \text { KAŞE NUMARASI } & : \text { XXXXX } \\ \text { İŞ ADRESİ } & : \text { X ADRESİ } \\ \text { TELEFON } & : \text { XXXX XXXXXXXXX } \\ \text { VERGİ DAİRESİ, HESAP NO } & : \text { X V.D / XXX XXXX XXXXX } \\ \text { 2-TESPİTİ YAPILAN ŞİRETINN: } \\ \text { UNVANI } & : \text { V OTOMASYON ÜRÜNLERIII } \\ \text { ADRES } & : \text { D ADRESİ } \\ \text { VERGİ DAİRESİ, HESAP NO } & : \text { X V.D / XXX XXX XXXX } \\ \text { SERMAYESİ } & : 1.000 .000,00 € \\ \text { BİR ÖNCEKİSERMAYESİ } & : 50.000,00 €\end{array}$

3- GENEL BİLGİ:

V Otomasyon Ürünleri Sanayi ve Ticaret Limited Şirketi İSTANBUL Ticaret Sicil Müdürlüğü’nün XXXXXX numarasıyla kayıtlı olup X vergi dairesinin XXXXXXXXXX numaralı mükellefidir. Merkezi D adresindedir. Şirketin iştigal konusu sanayide kullanılan makinelere otomasyon yapmak olup, XX/XX/XXXX tarihi itibariyle sermayesi 1.000.000,00£’dir. Sermayenin tamamı ödenmiştir.

A- Hukuki Dayanak:

Türk Ticaret Kanunu'nun ilgili maddelerinde tür değişikliğine ilişkin hükümlere yer verilmiştir. Bu rapor kurumun faaliyetine tür değiştirmek suretiyle anonim şirket olarak devam etmek istemesi sebebiyle öz varlıklarının tespiti ile 31 Ekim 
2012 tarih ve 28453 sayılı Resmî Gazete'de yayımlanan "Şirketlerde Yapı Değişikliği ve Ayni Sermaye Konulmasında Siciller Arası İşbirliğine İlişkin Tebliğ" in 5. maddesinin (b) bendine istinaden şirketin aktifinde yer alan tescile tabi varlıkların (taşıtların) değer tespiti, önceki sermayenin ödendiği ve KOBİ statüsünün tespiti amacıyla düzenlenmiştir.

B- İletişim Araçları Hakkında Bilgi:

V Otomasyon Ürünleri Sanayi ve Ticaret Limited Şirketi adına kayıtlı olan XXX XXXXXXX numaralı telefonu ile XXX XXXXXX numaralı fax hattını kullanmaktadır.

C- Ortaklara ve Yönetim Organlarına İlişkin Bilgiler:

V Otomasyon Ürünleri Sanayi ve Ticaret Limited Şirketi'nin ortaklarının adları, adresleri ve T.C. kimlik numaraları aşağıdaki gibidir.

\begin{tabular}{lll} 
Ad-Soyad & T.C. Kimlik No & Adres \\
1.ORTAK & XXXXXXXXXXXX & K ADRESİ \\
2.ORTAK & XXXXXXXXXXXX & L ADRESİ \\
ORTAĞIN ADI SOYADI & PAY ORANI & PAY TUTARI \\
\hline 1.ORTAK & $\% 51$ & $510.000,00 €$ \\
2.ORTAK & $\% 49$ & $490.000,00 €$
\end{tabular}

X Noterliği tarafından düzenlenen XX/XX/XXXX tarih ve XXXXX sayılı imza sirkülerine göre XXXXXXXXXXX T.C. kimlik numaralı 2.ORTAK ile XXXXXXXXXX T.C. kimlik numaralı 1.ORTAK 10 (on) yıl süre ile şirket müdürü olarak münferit imzaları ile şirketi temsil ve ilzama yetkilidirler.

4- USUL İNCELEMELERİ:

V Otomasyon Ürünleri Sanayi ve Ticaret Limited Şirketi 2013 takvim yılında kullanmış olduğu kanuni defterlerinin noter tasdik bilgileri aşağıdaki gibidir.

$\begin{array}{llll}\text { YILI } & \text { YASAL DEFTERIN NEVI } & \text { TASDİK MAKAMI } & \text { TASDİK TARİHİ/ NO.SU } \\ 2013 & \text { Yevmiye Defteri } & \text { X NOTERİ } & \text { XX.XX.XXX / XXXXX } \\ 2013 & \text { Kebir Defteri } & \text { X NOTERİ } & \text { XX.XX.XXX / XXXXX } \\ 2013 & \text { Envanter Defteri } & \text { X NOTERİ } & \text { XX.XX.XXX / XXXXX }\end{array}$

V Otomasyon Ürünleri Sanayi ve Ticaret Limited Şirketi’ne ait kanuni defterlerin TTK, 213 sayılı Vergi Usul Kanunu (VUK) ve Muhasebe Sistemi Uygulama Genel Tebliği (MSUGT) hükümlerine uygun tutulduğu tespit edilmiştir.

5- SERMAYENİN ÖDENDİĞINE DAİR İNCELEMELER:

Sermayenin ödendiği yıllara ait defterler:

$\begin{array}{llll}\text { YILI } & \text { YASAL DEFTERİN NEVİ } & \text { TASDİK MAKAMI } & \text { TASDİK TARİHİ/NOSU } \\ 2012 & \text { Yevmiye Defteri } & \text { X NOTERİ } & \text { XX.XX.XXX / XXXXX } \\ 2012 & \text { Kebir Defteri } & \text { X NOTERİ } & \text { XX.XX.XXX / XXXXX } \\ 2012 & \text { Envanter Defteri } & \text { X NOTERİ } & \text { XX.XX.XXX / XXXXX }\end{array}$

Nakdi sermaye ödemelerinin yevmiye kayıtları:

NAKDİ SERMAYE ÖDEMELERININ TARİHI TUTARI YEVMIYE MADDESI

$22 / 03 / 2012$

$70.477,83$

1053 

$22 / 03 / 2012$
$491.910,37$
1054
$22 / 03 / 2012$
$387.611,80$
1055

Şirketin sermayesini 50.000,00€’den 1.000.000,00€’ye çıkarması nedeniyle oluşan 950.000,00€ sermaye artış1, kar yedeği olan DAĞITILMAMIŞ GEÇMIŞ YIL KARLARINDAN karşılanmıştır, Buna göre şirketin sermayesi 1.000.000,00€ olup tescili 28/03/2012 günlü 8036 sayılı Ticaret Sicil Gazetesi'nin X sayfasında ilan edilmiştir.

6- DAĞITILMAYAN GEÇMIŞ YIL KARLARININ VE SERMAYE DÜZELTMESİ OLUMLU FARKLARININ SERMAYEYE İLAVESININN TESPITII:

Sermayenin 1.000.000,00€'den 5.000.000,00€’ye çıkartılmasını ve artrılan 3.994.540,50€’nin DAĞITILMAMIŞ GEÇMIŞ YIL KARLARINDAN, 5.459,50£'nin SERMAYE DÜZELTMESİ OLUMLU FARKLARINDAN karşılanmasına karar vermiştir.

Sermaye artırımının geçmiş yıl karlarından karşılanan kısmının ilgili kanunlar ve muhasebe kurallarına göre tespiti aşağıdaki gibidir:

$\begin{array}{llll}\text { YILI } & \text { YASAL DEFTERIN NEVI } & \text { TASDİK MAKAMI } & \text { TASDİK TARİHİ/ NO.SU } \\ 2011 & \text { Yevmiye Defteri } & \text { X NOTERİ } & \text { XX.XX.XXX / XXXXX } \\ 2011 & \text { Kebir Defteri } & \text { X NOTERİ } & \text { XX.XX.XXX / XXXXX } \\ 2011 & \text { Envanter Defteri } & \text { X NOTERİ } & \text { XX.XX.XXX / XXXXX } \\ 2012 & \text { Yevmiye Defteri } & \text { X NOTERİ } & \text { XX.XX.XXX / XXXXX } \\ 2012 & \text { Kebir Defteri } & \text { X NOTERİ } & \text { XXXXX.XXX / XXXXX } \\ 2012 & \text { Envanter Defteri } & \text { X NOTERİ } & \text { XX.XX.XXX / XXXXX }\end{array}$

V Otomasyon Ürünleri Sanayi ve Ticaret Limited Şirketi'nin faaliyetleri dolayısıyla elde ettiği kazanç ve iratları ilgili yasal mevzuata uygun şekilde kayıtlarına intikal ettirmiştir. Şirketin, ilgili yıllar gayrisafi karlarından Tek Düzen Muhasebe Planı, VUK ve TTK mevzuatına uygun şekilde gerekli karşılıkları ayırdıktan sonra, geçmiş yıl karları 31/03/2013 tarihi itibariyle aşağıdaki şekildedir.

\begin{tabular}{lcl} 
YILI & TUTARI & YEVMIYE KAYDI TARİH/ NO.SU \\
\hline 2011 Y 11 kar1 & $1.746 .990,00 €$ & XX.XX.XXX / XXXXX \\
2012 Y $1 l_{1}$ kar1 & $2.294 .104,00 €$ & XX.XX.XXX / XXXXX \\
Toplam & $4.041 .094,00 €$ &
\end{tabular}

Sermaye artırımının sermaye düzeltmesi olumlu farklarından karşılanan kısmının ilgili kanunlar ve muhasebe kurallarına göre tespiti aşağıdaki gibidir:

$\begin{array}{llll}\text { YILI } & \text { YASAL DEFTERİN NEVI } & \text { TASDİK MAKAMI } & \text { TASDİK TARİHİ/NOSU } \\ 2004 & \text { Yevmiye Defteri } & \text { X NOTERİ } & \text { XX.XX. XXXX/XXXXX } \\ 2004 & \text { Kebir Defteri } & \text { X NOTERİ } & \text { XX.XX. XXXX/XXXXX } \\ 2004 & \text { Envanter Defteri } & \text { X NOTERİ } & \text { XX.XX. XXXX/XXXXX }\end{array}$

Sermaye düzeltmesi olumlu farklarının yevmiye kayıtları:

$\begin{array}{lll}\text { TARIHI } & \text { TUTARI } & \text { YEVMIYE MADDESİ NO } \\ 31.12 .2004 & 5.459,50 & 2886\end{array}$

7- KURUMUN ÖZ KAYNAĞININ İNCELENMESİ VE TESPİTİ:

A- İncelemenin Konusu ve Amac1: 
İstanbul Ticaret Sicil Müdürlüğü’nün XXXXXX numarasında kayıtlı bulunan V Otomasyon Ürünleri Sanayi ve Ticaret Limited Şirketi ortaklar kurulunun XX/XX/XXXX tarih ve XXXX/X sayılı kararında, şirket türünün TTK'nın ilgili maddeleri ile vergi kanununun ilgili maddeleri hükümlerine göre aynı ortaklar ve hisse oranları korunarak anonim şirkete dönüştürülmesine ve öz varlık tutarının tespitine karar verildiği görülmüştür.

\section{B- Bilanço Üzerinde Yapılan İncelemeler:}

TTK'nın 73. maddesinde Türkiye Muhasebe Standartları'nda aksi öngörülmemişse, bilançoda duran ve dönen varlıklar, öz kaynaklar, borçlar ve dönem ayırıcı hesapların ayrı kalemler olarak ve yeterli ayrıntıya inilerek gösterilmesi gerektiği belirtilmiştir.

VUK'un 192. maddesinde ise bilançonun aktif ve pasif olmak üzere iki tabloyu ihtiva ettiği, aktif tablosunda mevcutlar ile alacaklar (ve varsa zarar) pasif tablosunda borçların gösterileceği, aktif toplamı ile borçlar arasındaki farkın müteşebbisin işletmeye mevzu varlığını (özsermayeyi) teşkil ettiği belirtilmiştir. Kanunda ayrıca ihtiyatlar ve karların öz sermayenin cüzileri sayıldığı ifade edilmiştir. MSUGT'da ise özkaynağın, işletme sahip veya ortaklarının bilanço tarihinde işletmeye yapmış oldukları sermaye yatırımlarının tutarını gösteren ödenmiş sermaye ile sermaye yedekleri, kar yedekleri, geçmiş yıllar karları ve geçmiş yıllar zararları ve dönemin net kar veya zararını kapsadığı belirtilmiştir.

V Otomasyon Ürünleri Sanayi ve Ticaret Limited Şirketi bilançosunun aktif tarafında dönen ve duran varlıklarını, pasif tarafında ise borç ve özkaynaklarını göstermiş olup, bilanço kalemlerini yukarıda yapılan açıklamalar doğrultusunda gerekli alt hesapları açmak suretiyle düzenlemiştir.

Öz sermaye ve ana sermaye kavramı; özvarlık veya özkaynak olarak da ifade edilmektedir.

C- Özvarlık Tutarının Hesaplanması:

V Otomasyon Ürünleri Sanayi ve Ticaret Limited Şirketi tarafından tarafımıza sunulan 31.03.2013 tarihli ara bilanço ile bu döneme ilişkin kanuni defter kayıtları ve ilgili belgeler esas alınarak şirketin özvarlığı aşağıdaki şekilde tespit edilmiştir.

V Otomasyon Ürünleri Sanayi ve Ticaret Limited Şirketi’nin 31.03.2013 tarihli ara bilançosuna göre tespit edilen öz kaynak (varlık) unsurları ise aşağıdaki gibidir.

\section{ÖDENMIŞ SERMAYE $\quad: 1.005 .459,00 €$}

KAR YEDEKLERİ (YASAL YEDEKLER) : 900.317,00€

\section{KIST DÖNEM KARI}

GEÇMIŞ YILLAR KARLARI

ÖZKAYNAKLAR TOPLAMI
: 191.524,00€

: 4.041.094,00€

: 6.138.395,00€

Yukarıda yapılan açıklamalarımıza göre, kurumun özvarlığı (özkaynak) tutarı 6.138.395,45€ olarak tespit edilmiştir. Buna göre yasal yedekler esas sermayenin \%50'sini aştığından öz kaynaklar arasında gösterilen 900.317,00€ tutarındaki serbest fon niteliği kazanan yasal yedeklerin sermayeye eklenmesi mümkündür. Buna göre özkaynaklar hesap grubunda gösterilen 1.005.459,00€ ödenmiş sermaye ile 4.041.094,00€ tutarındaki geçmiş yıllar karlarına 191.524,00€ tutarındaki kıst dönem karı ve kar yedekleri (yasal yedekler) eklendikten sonra bulunan 6.138.395,00€’nin yeni kurulacak anonim şirkete TTK'nın 462. maddesine göre sermaye olarak konulması mümkün bulunmaktadır.

\section{8- TÜR DEĞİŞİKLIĞİ SONUCUNDA KURULACAK ANONIM ŞİRKETE DEVREDİLECEK OLAN} TESCILE TABİ VARLIKLARIN DEĞERININ TESPITİ:

Gümrük ve Ticaret Bakanlığı tarafından XX/XX/XXX tarih ve XXXXXX sayılı Resmi Gazete'de yayımlanan "Şirketlerde Yapı Değişikliği ve Ayni Sermaye Konulmasında Siciller Arası İşbirliğine İlişkin Tebliğ"de, birleşme, bölünme ve tür değiştirme gibi yapı değişiklikleri ile ayni sermaye konulması veya ticari işletmelerin devralınması sonucunda, tapu ve gemi sicili ile fikri mülkiyete ilişkin sicillerde ve benzeri sicillerde kayıtlı bulunan mal ve hakların sahipliklerinde meydana gelen değişikliklerin ilgili sicillere bildirilmesini ve sicil kayıtları ile belgelerindeki gerekli değişikliklerin yapılmasına ilişkin usul ve esaslar açıklanmıştır. 
Söz konusu tebliğin 4. maddesinin 2. fikrasında ticaret şirketlerinin TTK hükümlerine göre tür değiştirmelerinde, tür değiştiren şirketin mal varlığına dahil olan tapu, gemi ve fikri mülkiyet sicilleri ile benzeri sicillerde kayıtlı bulunan mal ve hakların yeni tür adına tescilinin gecikmeksizin yapılması amacıyla, tescili yapan müdürlük tarafından yeni türün tescili ile eş zamanlı olarak ilgili sicillere tebliğin 5. maddesinde düzenlenen hususları bildirmekle yükümlü tutulmuştur.

i-Tebliğin 5. maddesinin 1. fikrasının (b) bendinde tür değişikliğinde mülkiyet değişikliğine konu olan mal ve hakların yeminli mali müşavir veya serbest muhasebeci mali müşavirin, denetime tabi şirketlerde ise denetçi tarafından tespit edilen değerinin,

ii-Tebliğin 5. maddesinin 1. fikrasının (f) bendinde ise, tür değişikliği durumunda yeni türün tescil edildiği,

- Eski şirketin unvanı,

- Yeni türün unvanı,

- Yeni türün adresi,

- Ticaret sicili numarası,

- Ortaklık yapisı,

- Şirkete temsile yetkili olanların adı, soyadı ve T.C. kimlik numarasının,

Bildirilmesi gerektiği, bu bildirime yeni hak sahibi şirketin şirket sözleşmesi ile değerlemeye ilişkin raporların birer örneğinin ekleneceği belirtilmiştir.

TTK'nın 180. maddesinde "Bir şirket hukuki şeklini değiştirebilir. Yeni türe dönüştürülen şirket eskisinin devamıdır" hükmü yer almaktadır. Anılan madde hükmüne göre tür değiştiren şirket eski şirketin devamı niteliğindedir. Öte yandan şirket ortaklar kurulunun XX/XX/XXX tarih ve XXXX/XX sayılı kararında TTK hükümlerine göre kurulmuş olan limited şirketin yine TTK’nın ilgili maddeleri ve Kurumlar Vergisi Kanunu'nun 19 ve 20. maddelerine göre tür değiştirmek suretiyle tüm aktif ve pasifleriyle bir bütün halinde anonim şirkete dönüştürülmesine karar vermiştir. Dolayısıyla tescile tabi taşınmazlar ve taşıtların değer tespitinde şirketin 31.03.2013 tarihli ara bilançosunda yer alan kayıtlı değerleri esas alınmıştır.

Taşıtlar:

Tablo 5. Örnekle İlgili Araç Listesi

\begin{tabular}{|l|l|l|l|l|l|l|l|l|}
\hline & Plaka & Model & $\begin{array}{l}\text { Model } \\
\text { Yllı }\end{array}$ & $\begin{array}{l}\text { Kasko } \\
\text { Değeri }\end{array}$ & $\begin{array}{l}\text { Araç } \\
\text { Tipi }\end{array}$ & $\begin{array}{l}\text { Tescil } \\
\text { Tarihi }\end{array}$ & $\begin{array}{l}\text { Tescil } \\
\text { Numaras }\end{array}$ & $\begin{array}{l}\text { Tescil Oldukları } \\
\text { Sicil Müdürlüğ̈ }\end{array}$ \\
\hline 1 & ${ }^{* *} \mathrm{xx} x^{* * * *}$ & $\mathrm{Y}$ & 2008 & 16.525 & $\mathrm{~A}$ & $\mathrm{xx} / \mathrm{xx} / \mathrm{xxxx}$ & $\mathrm{xxxxxxx}$ & $\mathrm{X}$ \\
\hline 2 & ${ }^{* *} \mathrm{xx} \mathrm{x}^{* * * *}$ & $\mathrm{Y}$ & 2010 & 19.205 & $\mathrm{~B}$ & $\mathrm{xx} / \mathrm{xx} / \mathrm{xxxx}$ & $\mathrm{xxxxxxx}$ & $\mathrm{X}$ \\
\hline 3 & ${ }^{* *} \mathrm{xx} \mathrm{x}^{* * * *}$ & $\mathrm{Y}$ & 2011 & 21.784 & $\mathrm{C}$ & $\mathrm{xx} / \mathrm{xx} / \mathrm{xxxx}$ & $\mathrm{xxxxxxx}$ & $\mathrm{X}$ \\
\hline 4 & ${ }^{* *} \mathrm{xx}^{* * * *}$ & $\mathrm{Y}$ & 2011 & 24.190 & $\mathrm{D}$ & $\mathrm{xx} / \mathrm{xx} / \mathrm{xxxx}$ & $\mathrm{xxxxxxx}$ & $\mathrm{X}$ \\
\hline 5 & ${ }^{* *} \mathrm{xx}^{* * * *}$ & $\mathrm{Y}$ & 2011 & 24.190 & $\mathrm{E}$ & $\mathrm{xx} / \mathrm{xx} / \mathrm{xxxx}$ & $\mathrm{xxxxxxx}$ & $\mathrm{X}$ \\
\hline 6 & ${ }^{* *} \mathrm{xx}^{* * * *}$ & $\mathrm{Y}$ & 2011 & 26.728 & $\mathrm{~F}$ & $\mathrm{xx} / \mathrm{xx} / \mathrm{xxxx}$ & $\mathrm{xxxxxxx}$ & $\mathrm{X}$ \\
\hline 7 & ${ }^{* *} \mathrm{xx}^{* * * *}$ & $\mathrm{Y}$ & 2012 & 21.068 & $\mathrm{G}$ & $\mathrm{xx} / \mathrm{xx} / \mathrm{xxxx}$ & $\mathrm{xxxxxxx}$ & $\mathrm{X}$ \\
\hline 8 & ${ }^{* *} \mathrm{xx}^{* * * *}$ & $\mathrm{Y}$ & 2012 & 21.068 & $\mathrm{H}$ & $\mathrm{xx} / \mathrm{xx} / \mathrm{xxxx}$ & $\mathrm{xxxxxxx}$ & $\mathrm{X}$ \\
\hline 9 & ${ }^{* *} \mathrm{xx}^{* * * *}$ & $\mathrm{Y}$ & 2012 & 20.913 & $\mathrm{I}$ & $\mathrm{xx} / \mathrm{xx} / \mathrm{xxxx}$ & $\mathrm{xxxxxxx}$ & $\mathrm{X}$ \\
\hline 10 & ${ }^{* *} \mathrm{xx}^{* * * *}$ & $\mathrm{Y}$ & 2013 & 26.549 & $\mathrm{~J}$ & $\mathrm{xx} / \mathrm{xx} / \mathrm{xxxx}$ & $\mathrm{xxxxxxx}$ & $\mathrm{X}$ \\
\hline 11 & ${ }^{* *} \mathrm{xx}^{* * * *}$ & $\mathrm{Y}$ & 2013 & 26.549 & $\mathrm{~K}$ & $\mathrm{xx} / \mathrm{xx} / \mathrm{xxxx}$ & $\mathrm{xxxxxxx}$ & $\mathrm{X}$ \\
\hline 12 & ${ }^{* *} \mathrm{xx}^{* * * *}$ & $\mathrm{Y}$ & 2013 & 26.549 & $\mathrm{~L}$ & $\mathrm{xx} / \mathrm{xx} / \mathrm{xxxx}$ & $\mathrm{xxxxxxx}$ & $\mathrm{X}$ \\
\hline
\end{tabular}




\begin{tabular}{|c|c|c|c|c|c|c|c|c|}
\hline 13 & ${ }^{* *} \mathrm{xx}^{* * * *}$ & $\mathrm{Y}$ & 2013 & 28.547 & $\mathrm{M}$ & $\mathrm{xx} / \mathrm{xx} / \mathrm{xxxx}$ & xxxxxxx & $\mathrm{X}$ \\
\hline 14 & ${ }^{* *} \mathrm{xx}^{* * * *}$ & $\mathrm{Y}$ & 2010 & 53.305 & $\mathrm{~N}$ & $\mathrm{xx} / \mathrm{xx} / \mathrm{xxxx}$ & XXXXXXX & $\mathrm{X}$ \\
\hline
\end{tabular}

Yapılan incelemede V Otomasyon Ürünleri Sanayi ve Ticaret Limited Şirketi'nin tür değiştirmesi sonucunda yeni kurulacak V Otomasyon Ürünleri Sanayi ve Ticaret Anonim Şirketi adına tescil edilecek yukarıda belirtilen taşıtların ilgili trafik tescil müdürlüklerine bildirilmesi gerekmektedir. Taşıt ruhsatlarının fotokopisi ekte mevcuttur.

\section{9- KOBİ STATÜSÜNÜN TESPITTINE İLIŞKİN İNCELEME:}

TTK'nın 186. maddesinde tüm ortakların onaylaması halinde küçük ve orta ölçekli işletmelerin tür değiştirme raporunu düzenlemekten vazgeçebileceği belirtilmiştir. Bu nedenle tür değiştirecek olan adı geçen şirketin küçük veya orta ölçekli şirket olup olmadığının tespiti gerekmektedir.

Kurum 2012/3834 sayılı Bakanlar Kurulu Kararı ile değişiklik 19.10.2005 tarihli ve 2005/9617 sayılı Bakanlar Kurulu Kararı ile yürürlüğü konulan "Küçük ve Orta Büyüklükte İşletmelerin Tanımı, Nitelikleri ve Sınıflandırılması Hakkında Yönetmelik" (KOBİ yönetmeliği) hükümlerine göre küçük ve orta büyüklükte işletmeler aşağıdaki gibi tanımlanmıştır.

Yönetmeliğin 5. maddesinde elli kişiden az yıllık çalışan istihdam eden ve yıllık net satış hasılatı veya mali bilançosundan herhangi biri sekiz milyon TL sınırını aşmayan işletmeler "küçük işletme", iki yüz elli kişiden az yıllık çalışan istihdam eden ve yıllık net satış hasılatı veya mali bilançosundan herhangi biri kırk milyon TL sınırını aşmayan işletmeler "orta büyüklükteki işletme" olarak sınıflandırılmıştır (Bilanço tarihinin ait olduğu döneme ilişkin kriterler). Yönetmeliğin 6.maddesinde ise hesapların kapanış tarihinde, işletme sınıfları ve KOBİ vasfi belirlenirken dikkate alınan kriterlerden herhangi birini, birbirini takip eden iki hesap döneminde de kaybeden veya aşan işletmelerin sınıf değiştireceği veya KOBİ vasfını kaybedeceği belirtilmiştir. Buna göre bir şirketin küçük veya orta ölçekli şirket statüsünde olup olmadığına son iki hesap dönemindeki çalışan ve mali bilanço büyüklükleri dikkate alınarak tespit edilmesi gerekmektedir.

V Otomasyon Ürünleri Sanayi ve Ticaret Limited Şirketi 2011 hesap döneminde ortalama X kişi istihdam etmiş olup, 2011 yılında net satış hasılatı 9.492.606,00€, mali bilanço toplam1 4.560.028,00€, 2012 hesap döneminde ortalama X kişi istihdam etmiş olup, 2012 yllında net satıs hasılatı 10.959.116,00€, mali bilanço toplamı 6.515.336,00£'dir. Buna göre firma “Küçük ve Orta Büyüklükteki İşletmelerin Tanımı, Nitelikleri Sınıflandırılması Hakkındaki Yönetmelik” gereği küçük ve orta büyüklükte ölçekli işletme sayllmaktadır.

\section{0- SONUÇ:}

1- V Otomasyon Ürünleri Sanayi ve Ticaret Limited Şirketi'ne ilişkin kanuni defter ve belge kayıtları ve tarafımıza sunulan ara bilanço üzerinde yapılan incelemede, söz konusu finansal tabloların TTK ve 213 sayılı VUK hükümleri ile MSUGT açıklamalarına uygun olduğu, yapılan inceleme ve değerlendirmemize göre 31.03.2013 tarihi itibariyle öz varlığının 6.138.395,00€ olduğu tespit edilmiş olup, bu tutarın 4.000.000,00£’lik kısmının TTK’nın ilgili maddelerine göre tür değiştirme hükümleri gereğince yeni kurulacak anonim şirkete, anılan kanunun 462. maddesi uyarınca sermaye olarak konulmasında herhangi bir sakınca bulunmadığı,

2- Yukarıda değerleri ve özellikleri belirtilen taşıtların tür değişikliği sonucunda kurulacak anonim şirket adına tescili için her türlü değişikliğini tescil edecek olan İstanbul Ticaret Sicil Müdürlügü’nnce ilgili sicil müdürlüklerine gerekli bildirimi yapması gerektiği,

3- V Otomasyon Ürünleri Sanayi ve Ticaret Limited Şirketi'nin, sermayesini 1.000.000,00£'den 5.000.000,00£’ye çıkarması nedeniyle oluşan 4.000.000,00€ sermaye artşının, DAĞITILMAMIŞ GEÇMIŞ̧ YIL KARLARINDAN ve SERMAYE DÜZELTMESI OLUMLU FARKLARINDAN karşılanmasında yasal mevzuat açısından hiçbir sakınca olmadığ sonucuna varılmışır.

4- V Otomasyon Ürünleri Sanayi ve Ticaret Limited Şirketi'nin Küçük ve Orta Büyüklükte İşletmelerin Tanımı, Nitelikleri ve Sınıflandırılması Hakkında Yönetmelik hükümleri çerçevesinde "küçük ve orta ölçekli işletme" statüsünde bulunduğu, bu nedenle anılan kanunun ilgili 186. maddesi uyarınca tüm ortakların onaylaması halinde tür değiştirme raporu düzenlenmeyeceği, 
Sonuç ve kanaatine varılmıştır.

\section{2. 6. Tür Değişikliğinin İncelemeye Sunulması ve Şirket Müdürleri Tarafından Alınan Kararlar}

Hazırlanan rapor ve plan genel kurulda karar alınmasından otuz gün önce merkezinde ortakların incelemesine sunulmuştur ve tür değişikliği yapılmasında karar alınmıştır.

Karar örneği aşağıdaki gibidir:

\section{OTOMASYON ÜRÜNLERI SANAYİ VE TİCARET LIMITTED ȘİRKETI}

\section{SİCİL NO}

KARAR NO

KARAR TARİHI

\section{: XXXXXX}

: XXX/X

\section{: XX/XX/XXXX}

Ortaklar kurulu aşağıda yer alan hususları karar altına almışlardır:

1. Tür değiştirme planı ile son üç yılın finansal tabloları ve ara bilanço TTK'nın 188. maddesi gereğince otuz gün önce merkezimizde ortakların incelemesine sunulmuş ve inceleme hakkı kullanılmıştır.

2. Tür değiştirme planının kabulüne,

3. Şirketimizin anonim şirketine dönüştürülmesine karar verilmiştir.

Keyfiyetin tescil ve ilan edilmesine,

ORTAK

1.ORTAK

(AD-SOYAD, TC, İMZA)
ORTAK

2.ORTAK

(AD-SOYAD, TC, İMZA)

\section{2. 7. Tür Değişikliğinin Ticaret Siciline Tescil ve İlanı}

Şirket ortakları tarafından alınana karar ile tür değişikliği ticaret siciline bir dilekçe ile bildirilmiştir ve sözleşme tescil edilmiştir. Tür değişikliği yeni bir tüzel kişilik kazanmıştır ve ilgili kuruluşlara bir dilekçe yardımıyla bildirilmiştir.

\section{2. 8. Tür Değişikliğinin Hukuki Sonuçları}

V Otomasyon Ürünleri Sanayi ve Ticaret Limited Şirketi'nin V Otomasyon Ürünleri Sanayi ve Ticaret Limited Şirketi olarak tür değişikliğine gitmesinin, şirket tüzel kişiliği, ortaklar ve çalışanları açısından hukuki sonuçları aşağıdaki gibidir (Aras, 2019):

- Mevcut borç, alacak, hak ve yükümlülükler aynı şekilde devam eder.

- Yenilenmeye gerek olmaksızın varsa tüm dava ve icra takipleri aynı şekilde devam eder.

- Yenilenmeye gerek olmaksızın satış, kira, kredi ve iş sözleşmesi gibi tüm sözleşmeler geçerliliğini korur.

- Unvan değişikliğinin, şirket sahip olduğu varlıklardan sicil müdürlüklerine bağlı bulunanların, örneğin gayrimenkulleri tapu sicil müdürlüklerine, taşıtların trafik sicil müdürlükleri gibi sicil müdürlüklerine bildirilmesi gerekmektedir.

- Şirket ticaret sicilinde aynı sicil numarasını yeni unvanıyla kullanmaya devam eder.

- Ortakların sahip olduğu pay ve haklar aynen devam eder. İmtiyazlı pay ve intifa senedi sahipleri olsaydı hakların aynen verilmesi ya da tazminat ödenmesi gerekirdi.

- Alacak ve borç ilişkileri tür değiştirmeden etkilenmemektedir.

- Çalışanların ücret, ikramiye, kıdem ve izinleri aynı şekilde devam eder. 


\section{SONUÇ}

Ekonomik hayatın önemli unsurlarından biri ticaret şirketleridir. Ticaret şirketlerinin birleşme, bölünme ve tür değiştirmeleri şirketlerin gelişmişlik düzeyi ve teknolojik gelişmelere bağlı olarak artan bir şekilde gündeme gelmektedir. Bu değişimlere katkı sağlayacak unsurların başında ülkelerin hukuk sistemlerinde gerekli düzenlemelerin zamanında yapılması gelmektedir. Bu sebeple ticari hayatı düzenleyen hukuk kuralları birçok gelişmiş ülkede kısa aralıklarla gözden geçirilerek, gereken düzenlemelerin yapıldığı görülmektedir. Almanya’da 1994, İsviçre’de 2004 yılında bağımsız kanun konusu olan ticaret şirketlerinde birleşme, bölünme ve tür değiştirme ülkemizde TTK ile ivme kazanmış, birçok şirkette bu değişimlerden faydalanmıştır.

Tür değiştirmede, tüzel kişilik değişmemekte ve doğal olarak bir sona erme de söz konusu olmamaktadır. Diğer bir ifade ile, tür değiş̧iren yeni şirket, eskisinin devamı sayılmaktadır. Şirket, kendi kimliğini ve hukuki kişiliğini tür değişikliğine rağmen korumaktadır. Dolayısıyla seçilen hukuki tür veya şekil ile yeni bir kuruluş da söz konusu olmamaktadır. Sonuç olarak, tür değişikliğine rağmen ortaksal ve malvarlıksal ilişkiler, eskiden olduğu gibi aynen devam etmektedir.

Bu çalışmanın konusu, TTK'da sermaye şirketlerinde tür değiştirmedir. Bu çalışmanın amacı ise ülkemizdeki sermaye şirketlerinde tür değiştirmenin TTK kapsamında derinlemesine incelemek ve var olan yasal düzenlemelerle uygulamada nasıl yapıldığını göstermektir.

TTK ile yapılan düzenlemelerle ortakların sorumlulukları açısından farklılıkları bulunan şirketler arasında tür değişikliğinin mümkün olup olmadığı, şahıs şirketlerinden sermaye şirketlerine tür değişikliği yapılırken fesih ve tasfiyeye ihtiyaç olup olmadığı gibi konulardaki tartışmalara son nokta konulmuş, tür değiştirme ayrıntılı bir şekilde ele alınmıştır. Şahıs şirketlerinin kendi aralarındaki tür değiştirmelerinde özel bir düzenleme yapılmış, benzerlikleri ve farklılıkları dikkate alınarak tür değiştirmenin usulleri belirlenmiştir. Kollektif ve komandit şirketlerde çeşit ve sorumluluk açısından farklı ortaklık yapılarına sahip olmalarına rağmen, farklılıklar ortadan kaldırılırsa tür değişikliği ile ilgili diğer hükümlerin uygulanmasına gerek olmadan tür değiştirebilmeleri kabul edilmiş, böylelikle şahıs şirketlerinin kendi aralarında tür değiştirmelerinde kolaylık sağlanmıştır.

ETTK'da tür değişikliğinde şirketler aynı türden olmak zorundaydı ama TTK ile getirilen yenilikte, şirketlerin türlerine bakılmaksızın (istisnalar var) tür değişikliği yapılabilmektedir. Böylelikle şirketler piyasa şartlarına göre veya avantajlarından yararlanmak istediği şirkete, diğer şirketini kapatmadan tür değiştirme yoluyla geçiş yapabilmektedir. TTK'da tür değişikliğinde limited şirketin özvarlığının ilgili mahkemece tespit ettirilmesi gerekliydi ama TTK ile bu durum ortadan kalkmaktadır ve bir mali müşavirin yazdığı özvarlık raporu yeterli kılınmaktadır. Tür değiştirme işlemlerinde böylelikle kolaylık sağlanılmıştır.

Tür değişikliğinde, ETTK'da limited şirket ile anonim şirketlerin asgari ortak sayılarındaki farklılıktan (limited şirkette en az 2, anonim şirkette ise en az 5) kaynaklanan birtakım sorunlar olmaktaydı, 2 ortaklı limited şirket anonim şirkete dönüşebilmesi için 5 ortak olma zorunluluğu vardı ama TTK ile artık her iki şirkette de asgari ortak sayısının bire düşmesi, tür değişikliğini kolaylaştırmıştır. Türkiye Odalar ve Borsalar Birliği'nin sitesinde yer alan istatistiklerde, 2018 yılında toplam 4.060 şirket tür değişikliğine gitmiş ve bu tür değişikliklerinden 1.470 tanesi limited şirketin anonim şirkete dönüşmesi şeklinde gerçekleşmiştir. TTK ile çok sayıda şirket tür değişikliğine gitmiş olması, tür değişikliğinin kolaylaymış olduğu göstermekte, ayrıca istatistiklerde TTK'nın yürürlüğe girdiği tarihten beri daha çok sayıda şirketin tür değişikliğine gittiği görülmektedir.

TTK ile getirilen yeniliklerle limited şirketler ve anonim şirketlerde uygulama bakımından çok farklılık kalmamakta hatta avantajlarına bakıldığında anonim şirketlerin limited şirketlere kıyasla daha avantajlı olduğu görülmektedir. Hem farklarının azalması hem de avantajları sebebiyle önümüzdeki günlerde daha çok sayıda limited şirketin hızla anonim şirkete dönüşeceğini söyleyebilmekteyiz.

\section{Kaynakça}

Aras, Ç. (2019). “Sermaye Şirketlerinde Tür Değiştirme” On İki Levha Yayıncllık, İstanbul

Gülçiçek, A. (2012). “Yeni Türk Ticaret Kanunu’na Göre Şirketlerin Tür Değiştirme İşlemleri” Vergi Sorunları Dergisi, 286: 77-86. 
Hayreddin, E. (2012). “Yeni Türk Ticaret Kanunu'na Göre Tür Değiştirme Yol Haritası ve Nisapları” Yaklaşım Yayınları, 239.

Öztürk, N. (2012). “Ticaret Şirketlerinde Birleşme, Bölünme ve Tür Değiştirme Hükümleri (Genel Bir Bakış)” Yaklaşım Dergisi, 238.

Pulaşlı, H. (2012). "Yeni Şirketler Hukukun Genel Esasları” Adalet Yayınevi, Ankara

Tepeli, H. (2012). "Yeni Türk Ticaret Kanunu’na Göre Geçerli Tür Değişikliği” Yaklaşım Dergisi, 229.

Tepeli, H. (2012). "Yeni Türk Ticaret Kanunu'na Göre Kollektif Şirketin Komandit Şirkete, Komandit Şirketin Kollektif Şirkete Dönüşmesi” Yaklaşım Dergisi, 230.

Türk Ticaret Kanunu 31.07.2012 tarih- 6102 sayılı Kanun.

Yerci, C. (2011). “Yeni Türk Ticaret Üzerine Şirketlerin Tür Değiştirmesi” Vergi Sorunları Dergisi, 274:44-64.

\section{İnternet Kaynakları}

https://www.tobb.org.tr/BilgiErisimMudurlugu/Sayfalar/KurulanKapananSirketistatistikleri.php 14.11.2019 Erişim Tarihi: 04/02/2019 